\title{
Thyroid-stimulating Antibody Activity between Different Immunoglobulin G Subclasses
}

\author{
Anthony P. Weetman, ${ }^{*}$ Martin E. Yateman, ${ }^{\ddagger}$ Patricia A. Ealey, ${ }^{\ddagger}$ Charlotte M. Black, ${ }^{5}$ Charles B. Reimer, ${ }^{\text {st }}$ \\ Ralph C. Williams, Jr.," Brian Shine," and Nicholas J. Marshall ${ }^{\ddagger}$ \\ *Department of Medicine, University of Cambridge Clinical School, Addenbrooke's Hospital, Cambridge, CB2 2QQ, United Kingdom; \\ ${ }^{\ddagger}$ Department of Chemical Pathology, University College Hospital, London, EC1 6AU, United Kingdom; ${ }^{\S}$ Division of Host Factors, \\ Center for Infectious Diseases, Centers for Disease Control, Public Health Service, United States Department of Health and Human \\ Services, Atlanta, Georgia 30333; "Division of Clinical Immunology, Rheumatology and Allergy, University of Florida, Gainesville, \\ Florida 32610; and "Department of Chemical Pathology, Institute of Ophthalmology, London EC1V 9AT, United Kingdom
}

\begin{abstract}
To investigate the distribution of thyroid-stimulating antibody (TSAb) activity between IgG subclasses, sera from 11 patients with Graves disease (including the National Institute of Biological Standards and Control (NIBSC) Research Standard, long acting thyroid stimulator-B) were fractionated by chromatography on affinity columns of monoclonal IgG subclass antibodies or protein $A$ to deplete all but a single subclass. The resulting fractions were $98 \%$ or more pure for a single subclass. In all 11 patients, TSAb activity appeared to be confined to the IgG $_{1}$ fraction as determined by cAMP production on addition of the fractions to the FRTL-5 rat thyroid cell line. In all of eight specimens from seven patients so tested, the whole serum activity was recovered in the $\mathrm{IgG}_{1}$ fraction, after adjusting for the recovery of the isotype from the column. TSAb activity in one serum comprised both lambda and kappa light chains but was IgG 1 restricted. This IgG subclass restriction was not found when the same fractions were tested for thyroglobulin, microsomal/thyroid peroxidase, or tetanus toxoid antibody activity. Together with previous results showing marked restriction of both light chain usage and isoelectric point of TSAb, these results support the idea that Graves' disease may be the result of an oligo- or possibly monoclonal response at the $B$ cell level. (J. Clin. Invest. 1990. 86:723-727.) Key words: Graves' disease $\bullet$ thyroid-stimulating antibodies $\bullet$ IgG subclasses
\end{abstract}

\section{Introduction}

It is now clear that Graves' disease is caused by thyroid-stimulating antibodies (TSAb) ${ }^{1}$ which both bind to and stimulate the thyrotropin-stimulating hormone (TSH) receptor (1-5). A remarkable property of TSAb is that the activity is often confined to antibodies with only a single class of light chain. Although two studies $(6,7)$ reported that in most cases $(17$ out of

\footnotetext{
${ }^{\dagger}$ Deceased.

Address reprint requests to A. P. Weetman, Department of Medicine, Level 5, Addenbrooke's Hospital, Cambridge, CB2 2QQ, UK.

Received for publication 5 July 1989 and in revised form 2 May 1990.
}

1. Abbreviations used in this paper: LATS-B, long acting thyroid stimulator-B; M/TPO, microsomal antigen/thyroid peroxidase; $\mathrm{Tg}$, thyroglobulin; TSAb, thyroid-stimulating antibodies.

J. Clin. Invest.

(c) The American Society for Clinical Investigation, Inc. 0021-9738/90/09/0723/05 \$2.00

Volume 86, September 1990, 723-727
19 in total) only the lambda light chain was found in TSAb, we have found a more mixed pattern (8), in which some TSAb are lambda light chain restricted, some are kappa light chain restricted, and some are apparently unrestricted. Overall however, these results indicate that in many patients with Graves' disease there is restricted heterogeneity in the use of light chains by TSAb, which contrasts the unrestricted light chain heterogeneity of thyroglobulin ( $\mathrm{Tg}$ ) and microsomal antigen/ thyroid peroxidase (M/TPO) antibodies (9).

Bioactivity of TSAb requires the appropriate physical combination of both heavy and light chains $(6,10)$, suggesting that restriction of light chain type might be accompanied by restriction of heavy chain isotype. That TSAb may not be polyclonal is of importance in understanding the etiology of the disease. Moreover, the IgG subclass may have a major bearing on the functional capabilities of an antibody, in particular with regard to complement fixation $(11,12)$. Although complement activation is not necessary for the bioactivity of TSAb, we have found that terminal complement complexes can be identified around the thyroid follicles in Graves' disease, and such complexes are also elevated in the serum of these patients (13). These may relate to TPO antibody formation, and the paucity of TSH receptors on thyroid cells may preclude cross-linking and complement fixing. However, if TSAb did fix complement, this could modify the action of these antibodies on thyroid cells, in keeping with the effect of sublytic amounts of complexes on other cell types (14). We have therefore fractionated 11 Graves' sera by depletion of all but a single IgG subclass, using monoclonal anti-IgG subclass affinity columns to determine whether there is restricted heterogeneity of TSAb in heavy chain usage.

\section{Methods}

Serum. Samples were obtained from nine patients with Graves' disease, selected by prior assay for high TSAb potency. In addition we used long acting thyroid stimulator-B (LATS-B) (NIBSC Research Standard B, 65/122) and a new candidate reference material (coded 9/11), both of which were obtained from the National Institute of Biological Standards and Control, Mill Hill, London. Each of these are freeze dried preparations of dilutions of patient sera that have been selected for their high potency in the LATS in vivo bioassay. They were reconstituted in the appropriate volume of sample buffer (see below) before use and designated patients $F$ and $G$, respectively.

Sample preparation. IgG subclass depletion was performed using affinity columns as described in detail elsewhere (15). Monoclonal antibodies against IgG subclasses, described in detail elsewhere (16), were coupled to cyanogen bromide-activated Sepharose CL 4B (Pharmacia Fine Chemicals, Uppsala, Sweden) at a concentration of 5-10 $\mathrm{mg}$ antibody $/ \mathrm{ml}$ of packed beads; $>99 \%$ binding of each monoclonal 
antibody was achieved. Free sites were blocked with $2 \mathrm{M}$ glycine, and small scale columns for each coupled monoclonal reagent were tested for absorptive capacity using normal serum. From these results, three mixed bed columns were made with appropriate volumes of gel to isolate total $\mathrm{IgG}_{1}, \mathrm{IgG}_{2}$, and $\mathrm{IgG}_{4} . \mathrm{IgG}_{1}$ preparation used beads coupled to HP6014 (anti-IgG $2 ; 4 \mathrm{ml}$ ), HP6002 (anti-IgG $2 ; 0.5 \mathrm{ml}$ ), HP6047 (anti-IgG $33.5 \mathrm{ml}$ ), and HP6025 (anti-IgG ${ }_{4} ; 3.5 \mathrm{ml}$ ); $\mathrm{IgG}_{2}$ preparation used HP6069 (anti-IgG $; 4.5 \mathrm{ml}$ ), HP6019 (anti-non- $-\mathrm{IgG}_{2}$; $4 \mathrm{ml}), \mathrm{HP} 6047(2 \mathrm{ml})$ and $\mathrm{HP} 6025(3 \mathrm{ml})$, and $\mathrm{IgG}_{4}$ preparation used HP6069 (5.5 ml), HP6014 (3.5 ml), HP6002 $(0.5 \mathrm{ml})$, and HP6047 (3.5 ml). $\mathrm{IgG}_{3}$ was prepared with a 3-ml column of protein A coupled to Sepharose 4B (Pharmacia Fine Chemicals) (Table I). Total $\mathrm{IgG}_{3}$ was prepared using protein A coupled to Sepharose 4B (Pharmacia Fine Chemicals). As a control, to assess any contribution from potential stimulators in serum such as IgA or IgM (which remained in each subclass depleted fraction), serum was also passed over a column composed of protein A ( $3 \mathrm{ml} \mathrm{gel})$ and HP6047 (3 ml) to deplete all IgG; this fraction was termed non-IgG. The non-IgG fractions also formed individual patient controls against which the IgG subclass fractions were assessed in the TSAb bioassay (see below).

To isolate each isotype, $200 \mu \mathrm{l}$ of serum was applied to each column, which had been previously equilibrated with five bed volumes of run buffer $(0.5 \mathrm{M} \mathrm{NaCl}, 0.01 \mathrm{M}$ Tris- $\mathrm{HCl}, \mathrm{pH} \mathrm{8.0)}$, and collected under gravity with absorbance monitoring at $280 \mathrm{~nm}$. For $\mathrm{IgG}_{1}, \mathrm{IgG}_{2}$, and $\mathrm{IgG}_{4}$, preparations of the appropriate three fractions were pooled; only two fractions were required for the $\mathrm{IgG}_{3}$ and non-IgG preparations. Bound material was eluted from the columns with $3 \mathrm{M} \mathrm{Na}$ thiocyanate (SCN), discarded, and the columns reequilibrated in run buffer before the next run. The appropriate pooled fractions were concentrated (Minicon concentrator type 8-15; Amicon Corp., Danvers, MA) and dialyzed against assay buffer (see below) before use.

Assays. The four IgG subclass concentrations of all serum samples and subclass-depleted fractions were determined by immuno-enzymometric assay (17). The same assay method was used to determine IgM concentrations in serum and non-IgG fractions, so that nonspecific losses in the recovery of the latter could be estimated. In this case, the monoclonal antibody HP6083, against IgM, was used to coat the plates (1:1,000 dilution of ascites in water) as described for the assay for the IgG subclasses (17). The assay was developed after the addition of sample, using goat anti-human IgM-alkaline phosphatase conjugate

Table I. TSAb Activity of the IgG $G_{3}$ and $\operatorname{IgG}_{4}$ Fractions from Patients $A, H$, and $I$

\begin{tabular}{clcc}
\hline Patient & Fraction & IgG concentration & cAMP production \\
\hline \multirow{4}{*}{$A$} & & $m g / m l$ & $\%$ \\
& Serum & $1.0\left(\mathrm{IgG}_{1}\right)$ & $1681 \pm 182^{*}$ \\
& $\mathrm{IgG}_{1}$ & 1.0 & $1590 \pm 227$ \\
& $\mathrm{IgG}_{3}$ & $0.19^{\ddagger}$ & $105 \pm 28$ \\
$\mathrm{H}$ & $\mathrm{IgG}_{4}$ & 0.32 & $124 \pm 23$ \\
& $\mathrm{IgG}_{1}$ & 0.5 & $776 \pm 127$ \\
& $\mathrm{IgG}_{3}$ & 0.24 & $81 \pm 14$ \\
$\mathrm{I}$ & $\mathrm{IgG}_{4}$ & 0.22 & $105 \pm 18$ \\
& $\mathrm{IgG}_{1}$ & 1.0 & $520 \pm 140$ \\
& $\mathrm{IgG}_{3}$ & 0.18 & $100 \pm 10$ \\
& $\mathrm{IgG}_{4}$ & 0.20 & $110 \pm 20$
\end{tabular}

\footnotetext{
* Results are expressed as the mean $\pm \mathrm{SD} \%$ of cAMP formed by FRTL-5 cells in the presence of the non-IgG fraction, which was termed $100 \%$, from each patient.

${ }^{\ddagger}$ The $\mathrm{IgG}_{3}$ and $\mathrm{IgG}_{4}$ fractions were each derived from $1 \mathrm{ml}$ of serum and the entire yield was used; the $\mathrm{IgG}_{1}$ fraction was derived from $200 \mu \mathrm{l}$ serum and diluted to be equivalent to the values used in Fig. 1. The serum from patient $A$ was also diluted to give the same $\operatorname{IgG}_{1}$ concentration as the $\operatorname{IgG}_{1}$ fraction.
}

(1:1,000 dilution; Sigma Chemical Co., Poole, Dorset, UK) and pnitro-phenyl-phosphate as substrate. Dilutions of the WHO International Standard for human IgG, IgA, and IgM (67/97) were used to establish the concentration of IgM as well as the IgG subclasses (17).

Before commitment of the samples for the TSAb bioassay, the fractions, and in some cases, the unfractionated sera were dialyzed overnight against the bioassay buffer $\left(5 \mathrm{mM} \mathrm{KCl}, 1.3 \mathrm{mM} \mathrm{CaCl}_{2}, 0.4\right.$ $\mathrm{mM} \mathrm{Mg}_{2} \mathrm{SO}_{4}, 0.34 \mathrm{mM} \mathrm{Na}_{2} \mathrm{HPO}_{4}, 0.44 \mathrm{mM} \mathrm{KH}_{2} \mathrm{PO}_{4} 20 \mathrm{mM}$ Hepes, $1 \%$ glucose, $25 \mathrm{mM} \mathrm{NaCl}, 0.4 \% \mathrm{BSA}$, and $2 \mathrm{mM}$ IBMX, with a dialysis membrane exclusion point mol wt 12,000). Finally, the relative concentrations of the four subclass fractions derived from a given serum were adjusted (relative to the $\mathrm{IgG}_{1}$ concentration) to reflect those in the original serum. The IgG concentrations of the fractions containing IgG subclass 1 that were assayed for Fig. 1 were as follows: $A, 0.93 ; B, 0.42$; $C, 0.90 ; D, 0.45 ; E, 0.90 ; F(L A T S-B), 0.03 ; G, 0.07 ; H, 0.52 ; I, 1.0 ; J$, 0.53 ; and $K, 0.66 \mathrm{mg} / \mathrm{ml}$. The low apparent yield for patients $F(L A T S-B)$ and $G$ was the result of predilution of these reference preparations before distribution (see above). The sera tested concurrently in the assays were also diluted to give the same $\operatorname{IgG}_{1}$ concentrations as each individual $\operatorname{lgG}_{1}$ fraction; in this way the sera contained the same $\mathrm{IgG}_{2}, \mathrm{IgG}_{3}$, and $\mathrm{IgG}_{4}$ concentrations as the respective fractions that were assayed simultaneously. The dilution of non-IgG was the same as for $\mathrm{IgG}_{1}$, as it contained $72 \pm 16 \%$ of the starting IgM concentration, predicting a recovery of non-IgG serum component within the range of the $\operatorname{lgG}_{1}$ fraction. The mean value for the non-IgG for each patient was always normalized to be $100 \%$. Since Fig. 1 is constructed from the results of separate experiments, no SD can be attached to this mean. Individual non-IgG values however were always obtained and used to show that there was no activity in individual fractions other than $\operatorname{IgG}_{1}$.

The potencies of the fractions were tested in a TSAb assay which relied upon the stimulation of cAMP production by FRTL-5 cells. As described in detail elsewhere (18), these cells were manipulated before the bioassay as follows. They were initially plated out at $2 \times 10^{5}$ cells/ml in 24-well microtiter plates ( $500 \mu \mathrm{l} /$ well; Nunc Multidish 24 , Nunclon Delta 1-43982; Nunc, Roskilde, Denmark), in the following medium: Coon's modified F-12 medium supplemented with $5 \%$ newborn calf serum; and (per milliliter) $1 \mathrm{mU}$ TSH, $10 \mu \mathrm{g}$ insulin, $10 \mathrm{mM}$ cortisol, $5 \mu \mathrm{g}$ transferrin, $10 \mathrm{ng}$ glycyl-L-histidyl-L-lysine acetate, $10 \mu \mathrm{g}$ somatostatin, $100 \mathrm{U}$ penicillin, and $100 \mu \mathrm{g}$ streptomycin (this is termed $6 \mathrm{H}$ medium). All incubations were at $37^{\circ} \mathrm{C}$ in $95 \%$ air $/ 5 \% \mathrm{CO}_{2}$ atmosphere in a humidified incubator. After $3 \mathrm{~d}$ the $6 \mathrm{H}$ medium was replaced by fresh medium from which the TSH had been omitted $(5 \mathrm{H})$. After a further $7 \mathrm{~d}$, including one additional medium change with $5 \mathrm{H}$, the cells were used for the TSAb assay. For this bioassay, $5 \mathrm{H}$ was replaced with the dialyzed fractions described above, and the cells incubated for $4 \mathrm{~h}$. The cAMP concentration in the medium was then determined by an in-house radioimmunoassay, using a specific antiserum kindly donated by Dr. Brent Williams of the University of Edinburgh, or by Professor A. M. McGregor, Kings College Hospital, London. Each fraction was assayed using three separate microcultures with each CAMP determination in duplicate. The final results were expressed as the percentage of cAMP formed in the presence of the non-IgG fraction obtained from the same patient. The non-IgG fractions did not significantly change the cAMP from that observed in the presence of bioassay buffer.

All fractions were also tested for $\mathrm{Tg}, \mathrm{M} / \mathrm{TPO}$, and tetanus toxoid antibodies by ELISA (15). Results were expressed as a percentage of the total absorbance, derived from the sum of absorbances for all four subclass fractions (after subtracting the background absorbance of an antibody negative serum control).

\section{Results}

Purity and yield of subclasses. The purity of each fraction was assessed by comparing the amount of each depleted subclass remaining in the fraction (three subclasses per fraction) with the amount of that subclass in the starting sample. The $\operatorname{IgG}_{1}$, 


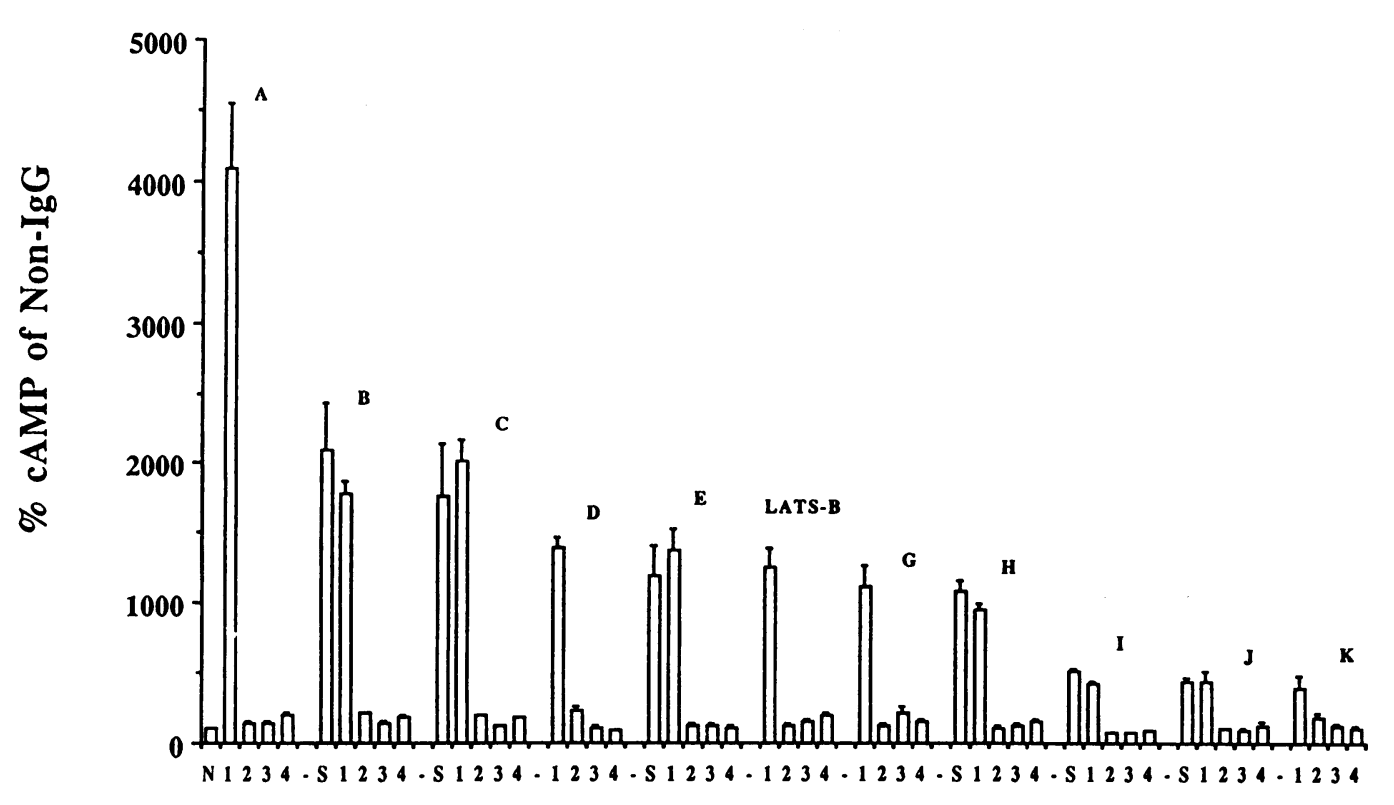

Figure 1. TSAb bioactivity of the IgG subclass fractions for patients $A-K$, including the reference preparations LATS-B and 9/11.

The latter is designated patient $G$. The results are expressed as the percentage of the cAMP formed by the FRTL-5 cells in the presence of the non-IgG fraction prepared from each patient $(n=3 \pm \mathrm{SD})$. The nonIgG fraction (shown as $N$ $=100 \%$ ) did not significantly alter the cAMP formed from that observed in the presence of bioassay buffer alone. $S$ represents dialyzed serum and the numbers 1-4 denote IgG subclass fractions $1-4$, respectively.
$\mathrm{IgG}_{2}$, and $\mathrm{IgG}_{3}$ fractions were all $>99 \%$ pure (i.e., for $\mathrm{IgG}_{1}$, less than $1 \%$ of the original $\mathrm{IgG}_{2}, \mathrm{IgG}_{3}$, or $\mathrm{IgG}_{4}$ remained, etc.). The $\mathrm{IgG}_{4}$ fractions were all $>99 \%$ pure with respect to $\mathrm{IgG}_{2}$ and $\mathrm{IgG}_{3}$, and $98 \%$ pure with respect to $\mathrm{IgG}_{1}$. The non-IgG fraction contained $<1 \%$ of the original $\operatorname{IgG}_{1}, \operatorname{IgG}_{2}, \mathrm{IgG}_{3}$, or $\mathrm{IgG}_{4}$. The mean $( \pm \mathrm{SD})$ yield, as a percentage of the starting concentration of each subclass in the 11 samples, was IgG $_{1}$ $71 \pm 15, \mathrm{IgG}_{2} 63 \pm 26, \mathrm{IgG}_{3} 73 \pm 20$, and $\mathrm{IgG}_{4} 71 \pm 19 \%$. Although roughly similar yields were obtained for each subclass, these fractions were nonetheless adjusted by appropriate dilution so that subclass concentrations for each specimen were proportional to those in the original serum before performing antibody assays. For the non-IgG fraction, the mean ( $\pm \mathrm{SD}$ ) yield of IgM was $72 \pm 16 \%$ of the starting concentration, and these fractions were used at the same dilutions as the $\mathrm{IgG}_{1}$ fraction without further adjustment.

$T S A b$ activity in subclass fractions. In all 11 specimens, $\mathrm{TSAb}$ activity was apparently confined to the $\operatorname{IgG}_{1}$ subclass with the other three subclass fractions, as well as the non-IgG fraction, being inactive (Fig. 1). In a separate experiment using fractions prepared from a second serum sample taken from patient $\mathrm{A}$, the $\mathrm{IgG}$ concentration of the $\mathrm{IgG}_{1}$ fraction was diluted to equal that of the $\mathrm{IgG}_{4}$ fraction $(0.071 \mathrm{mg} / \mathrm{ml})$ and to be below those of the $\operatorname{IgG}_{2}$ and $\mathrm{IgG}_{3}$ fractions. Greater than 3.5fold stimulation above the non-IgG control was still obtained with the $\mathrm{IgG}_{1}$ fraction (Fig. 2), but TSAb activity was undetectable with the $\mathrm{IgG}_{2}$ and $\mathrm{IgG}_{3}$ fractions, and the slight increase with $\mathrm{IgG}_{4}$ was insignificant $(P>0.05)$. In addition, this figure shows a comparison between serial dilutions of unfractionated serum and the $\mathrm{IgG}_{1}$ fraction, when within the limits of experimental error, a virtually parallel dose-response relationship was observed, and we confirmed the good recovery of TSAb activity in the $\mathrm{IgG}_{1}$ fraction.

As can be seen from Fig. 1, this restriction occurred over a wide range of TSAb potencies, and was also observed for the International Reference Preparation, LATS-B. For six other specimens besides $A(B, C, E, H-J)$, sufficient serum remained after fractionation to assay TSAb concurrently in the unfractionated material, and in all six cases the total bioactivity in the starting serum was recovered in the $\mathrm{IgG}_{1}$ fraction (Fig. 1). The mean recovery for these six was $101 \pm 16 \%$ (SD) (range $82-121 \%$ ). To ensure that these findings were reproducible, two of the samples were fractioned on two separate occasions with essentially similar results (not shown).

Because $\mathrm{IgG}_{3}$ and $\mathrm{IgG}_{4}$ each only comprise about $5 \%$ of the total IgG concentration, these two fractions were tested at a higher concentration than simply that proportional to the $\mathrm{IgG}_{1}$ concentration in whole serum, as in Fig. 1. A third serum sample from patient A (1 $\mathrm{yr}$ after the original sample in Fig. 1), and serum remaining from patients $H$ and $I$ was separated into an $\mathrm{IgG}_{1}$ fraction (from $200 \mu \mathrm{l}$ serum) as previously described, with $1 \mathrm{ml}$ of serum separated (in $200-\mu$ l aliquots) into $\mathrm{IgG}_{3}$ or $\mathrm{IgG}_{4}$ fractions. No TSAb activity was detected in these fractions despite the increase in the $\mathrm{IgG}_{3}$ and $\mathrm{IgG}_{4}$ concentrations

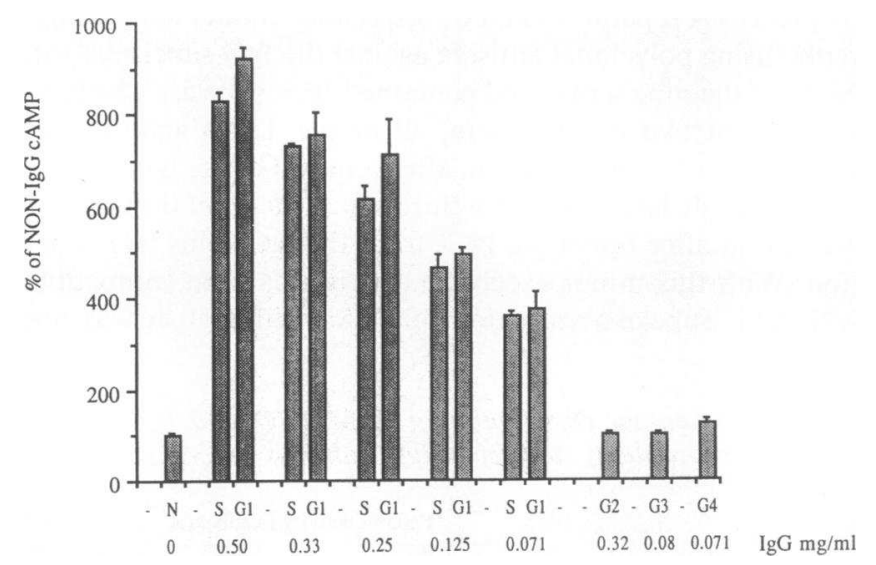

Figure 2. TSAb bioactivity of the IgG subclass fractions obtained from a fresh serum sample from patient $A$, with a serial dilution of the $\mathrm{IgG}_{1}$ fraction such that its final concentration equals that of the starting $\mathrm{IgG}_{4}$ fraction. The results from a parallel serial dilution of unfractionated serum are also shown for comparison. The results are expressed as the percentage of the cAMP formed by the FRTL- 5 cells in the presence of the non-IgG fraction prepared from this serum sample $(n=3 \pm \mathrm{SD}) . S$ represents dialyzed serum and the numbers $1-4$ denote IgG subclass fractions $1-4$, respectively. Whole serum $(S)$ IgG values refer to $\operatorname{IgG}_{1}$ content only. 
to $19-48 \%$ of that of the $\operatorname{IgG}_{1}$ tested (Table I). It can also be seen that all of the detectable reactivity in the whole serum from patient $A$ was recovered again in the $\mathrm{IgG}_{1}$ fraction, as in Fig. 2.

It was interesting that two of these sera had been previously assayed for light chain restriction (8). These were specimen D which was lambda light chain restricted and specimen $C$ which contained both lambda and kappa light chains. However, both sera appeared to be equally $\operatorname{IgG}_{1}$ heavy chain restricted.

Subclass activity of antibodies to $T g, M / T P O$, and tetanus toxoid. This IgG subclass restriction was not found for antibodies (in the same fractions) against tetanus toxoid, $\mathrm{Tg}$, or M/TPO, which were present in three, four, and seven of the subjects, respectively. As in Hashimoto's thyroiditis (15), $\mathrm{Tg}$ and $M / T P O$ antibodies were predominantly $\operatorname{IgG}_{1}, \mathrm{IgG}_{2}$, and $\mathrm{IgG}_{4}$ (Table II). There was proportionally more activity in the $\mathrm{IgG}_{4}$ fraction than would be expected from the low concentration of this subclass in serum (about $5 \%$ of the total IgG). The distribution of activity for antibodies against tetanus toxoid was variable but again present in $\mathrm{IgG}_{1}, \mathrm{IgG}_{2}$, and $\mathrm{IgG}_{4}($ Table II), with two of the three patients showing overrepresentation of the $\mathrm{IgG}_{4}$ subclass (26 and $76 \%$ of the total IgG antibody activity).

\section{Discussion}

Previous attempts to determine the IgG subclass distribution of the TSH receptor antibodies have suggested restricted heterogeneity, but the results have been inconclusive due to the lack of purity of the fractions obtained. Protein A depletion of $\mathrm{IgG}_{3}$ showed that there was no long-acting thyroid stimulator activity in this subclass (19), and $\mathrm{pH}$ gradient elution of protein A-bound IgG showed that the major (but not unique) component of TSH receptor binding activity resided in the $\mathrm{IgG}_{1}$ plus $\mathrm{IgG}_{4}$ fraction (20). However, further fractionation was not possible using this technique.

In the original report of light chain restriction of TSAb, an attempt was made to characterise the IgG subclass distribution by protein A separation and by sequential affinity chromatography' using polyclonal antisera against the IgG subclasses (6). None of the nine sera tested contained $\mathrm{IgG}_{3}$ subclass TSAb. In the case of two of these sera, all of the TSAb activity was recovered in the $\mathrm{IgG}_{1}$ fraction after removal of the $\mathrm{IgG}_{2}, \mathrm{IgG}_{3}$, and $\mathrm{IgG}_{4}$ subclasses, and in a third sample a slight diminution was found after removing $\operatorname{IgG}_{2}$ from the $\mathrm{IgG}_{1}$ plus $\mathrm{IgG}_{2}$ fraction. With this minor exception, the results were compatible with $\mathrm{IgG}_{1}$ subclass restriction of TSAb, although it was not

Table II. Percentage Distribution of Tg M/TPO, and Tetanus Toxoid (TT) Antibody Activity in IgG Subclass Fractions

\begin{tabular}{lcccc}
\hline & \multicolumn{4}{c}{ Percent activity in subclass } \\
\cline { 2 - 5 } & $\mathrm{IgG}_{1}$ & $\mathrm{IgG}_{2}$ & $\mathrm{IgG}_{3}$ & $\mathrm{IgG}_{4}$ \\
\hline Tg antibodies & $44 \pm 9^{*}$ & $19 \pm 10$ & $4 \pm 3$ & $31 \pm 11$ \\
$(n=4)$ & $(36-57)^{\ddagger}$ & $(10-31)$ & $(1-8)$ & $(20-44)$ \\
M/TPO antibodies & $43 \pm 21$ & $21 \pm 11$ & $3 \pm 2$ & $32 \pm 22$ \\
$(n=7)$ & $(12-81)$ & $(5-31)$ & $(0-6)$ & $(5-80)$ \\
TT antibodies & $55 \pm 38$ & $9 \pm 7$ & 0 & $35 \pm 38$ \\
$(n=3)$ & $(18-93)$ & $(5-17)$ & & $(2-76)$ \\
& & & & \\
\hline
\end{tabular}

* Mean \pm SD, ${ }^{\ddagger}$ Range. technically feasible at that time to assay the $\mathrm{IgG}_{2}$ and $\mathrm{IgG}_{4}$ fractions. The recent development of monoclonal antisubclass reagents has greatly facilitated the analysis of antibody IgG subclass distribution, providing large quantities of highly specific reagents, albeit without the capacity of protein $\mathrm{A}$. We and others have developed affinity columns using such monoclonal antibodies to select negatively for a single IgG subclass (15, $21,22)$; the mixed bed columns we have used are easier to manipulate than the sequential columns described by others and produce a higher yield of pure subclasses.

The present results in Graves' disease for $\mathrm{Tg}$ and M/TPO antibodies are similar to those in Hashimoto's thyroiditis (showing unrestricted activity), with proportional overrepresentation of the $\mathrm{IgG}_{4}$ subclass compared with the low proportion of this in total IgG although there was variation between patients (15). Direct assay of whole serum (by ELISA) for IgG subclasses had previously suggested a predominantly $\mathrm{IgG}_{4}$ subclass response, particularly for $\mathrm{Tg}$ antibodies, with little or no contribution from $\operatorname{IgG}_{2}$ or $\operatorname{IgG}_{3}(23,24)$, although this depended on the exact monoclonal reagents used in the assay (25). Again, there was considerable variation between patients with these assays. Affinity chromatography of serum containing $\mathrm{Tg}$ and M/TPO antibodies (using the methods now employed for TASb) confirmed this variability, demonstrating that the contribution from $\mathrm{IgG}_{4}$ is less, and from $\mathrm{IgG}_{2}$ more, than these assays would predict, and permitting functional analysis of the subclasses, which revealed a high relative functional affinity for the $\operatorname{IgG}_{2}$ subclass $\mathrm{Tg}$ and M/TPO antibodies (15).

In contrast, the results of the present study show unvarying apparent $\mathrm{IgG}_{1}$ subclass restriction of TSAb activity in all 11 patients studied. It remains possible that isotypes other than IgG $_{1}$ might contribute to TSAb activity, but at a level too low to be detectable by the bioassay. This possibility was examined in detail for patient A. Firstly, serial dilutions of the $\mathrm{IgG}_{1}$ fraction and its unfractionated serum appeared to give equivalent and parallel responses. In addition, the $\mathrm{IgG}_{1}$ fraction was added at the same $\mathrm{IgG}$ concentration as $\mathrm{IgG}_{4}$, and below that of $\mathrm{IgG}_{2}$ and $\mathrm{IgG}_{3}$, whereupon TSAb bioactivity was only observed with the $\mathrm{IgG}_{1}$ fraction. Finally $\mathrm{IgG}_{2}, \mathrm{IgG}_{3}$, and $\mathrm{IgG}_{4}$ fractions were added at higher proportions than in unfractionated serum (Table I and Fig. 2), such that they were increased to $19-64 \%$ of that of $\operatorname{IgG}_{1}$; but even at these relatively high concentrations, no TSAb activity was detected in the $\mathrm{IgG}_{2}$ $\mathrm{IgG}_{4}$ fractions. (A similar interpretation could also be made for the $\mathrm{IgG}_{3}$ and $\mathrm{IgG}_{4}$ fractions in patients $\mathrm{H}$ and $\mathrm{I}$, although a dose-response study was not performed.) These findings support the possibility that in all seven cases tested, the whole serum TSAb activity was likely to have been fully recovered in the $\mathrm{IgG}_{1}$ fraction. In contrast, the $\mathrm{IgG}_{2}, \mathrm{IgG}_{3}$, and $\mathrm{IgG}_{4}$ fractions in the patients studied, which showed no TSAb activity, were found to contain $\mathrm{Tg}, \mathrm{M} / \mathrm{TPO}$, or tetanus toxoid antibodies. These observations confirm and extend the report of $\mathrm{Za}$ karija (6), providing further evidence for restricted heterogeneity of TSAb with regard to heavy chain usage. It is notable that one serum (C), which when tested previously did not show light chain restriction (8), nevertheless was $\mathrm{IgG}_{1}$ restricted.

The regulation of murine antibody isotype secretion occurs at two levels, cognate interaction between $T$ and $B$ cells and interaction between $\mathrm{T}$ cell-derived lymphokines and $\mathrm{B}$ cells (26). Recently IL-4 has been defined as an important lymphokine regulating $\mathrm{IgE}$ and $\mathrm{IgG}_{4}$ subclass antibody production in man (27). Although it is possible that the isotype restriction we 
have observed for TSAb may be the result of T cell control, this does not easily account for the fact that all thyroid antibodies are synthesized together in the diseased gland $(28,29)$; it is difficult to envisage how aberrant $T$ cell regulation could affect TSAb IgG isotype selection and not that of $\mathrm{Tg}$ or M/TPO antibodies.

Moreover, TSAb are usually light chain as well as IgG isotype restricted, and earlier data showed an additional restriction of isoelectric point (30). These findings suggest that TSAb may be the product of a few clones or indeed, in some patients, a single clone of $B$ cells. Patients with unrestricted light chain usage (e.g., C), theoretically could have only two clones of cells producing TSAb. This situation contrasts that for Tg and M/TPO antibodies, which are light and heavy chain unrestricted; this in turn may be related to differences in pathogenicity of these autoantibodies. $\mathrm{Tg}$ and M/TPO are common in the general population, presumably because their effects are often not deleterious, in contrast to TSAb, which produce Graves' disease, making evolutionary pressure against the occurrence of TSAb much greater (31). Our evidence therefore supports the pauciclonality hypothesis of TSAb-producing $B$ cells $(7,31)$.

\section{Acknowledgments}

Dr. Weetman is a Wellcome Senior Research Fellow in Clinical Science, Dr. Ealey is grateful for support from the Sir Jules Thorn Charitable Trust, and Dr. Yateman is the recipient of a grant from the Locally Organised Research Scheme.

\section{References}

1. McKenzie, J. M., and M. Zakarija. 1977. LATS in Graves' disease. Recent Prog. Horm. Res. 33:29-53.

2. Manley, S. W. W., A. Knight, and D. D. Adams. 1982. The thyrotrophin receptor. Springer Semin. Immunopathol. 5:413-431.

3. Weetman, A. P., and A. M. McGregor. 1984. Autoimmune thyroid disease-developments in our understanding. Endocr. Rev. 5:309-355.

4. Burman, K. D., and J. R. Baker. 1985. Immune mechanisms in Graves' disease. Endocr. Rev. 6:183-232.

5. Rees Smith, B., S. M. McLachlan, and J. Furmaniak. 1988. Autoantibodies to the thyrotrophin receptor. Endocr. Rev. 9:106-121.

6. Zakarija, M. 1983. Immunochemical characterisation of the thyroid-stimulating antibody (TSAb) of Graves' disease: evidence for restricted heterogeneity. J. Clin. Lab. Immunol. 10:77-85.

7. Knight, J., P. Laing, A. Knight, D. Adams, and N. Ling. 1986. Thyroid-stimulating autoantibodies usually contain only $\lambda$-light chains: evidence for the "forbidden clone" theory. J. Clin. Endocrinol. Metab. 62:342-347.

8. Williams, R. C., N. J. Marshall, K. Kilpatrick, J. Montano, P. M. Brickell, M. Goodall, P. A. Ealey, B. Shine, A. P. Weetman, and R. K. Craig. 1988. Kappa/lambda Ig distribution of Graves' thyroid stimulating antibodies. Simultaneous analysis of $C \lambda$ gene polymorphisms. $J$. Clin. Invest. 82:1306-1312.

9. Laing, P. 1983. Both kappa and lambda light chain types are present in thyroid microsomal and thyroglobulin antibodies. Proc. Univ. Otago Med. Sch. 61:75-77.

10. Meek, J. C., A. E. Jones, U. J. Lewis, and W. P. VanderLaan. 1964. Characterization of the long-acting thyroid stimulator of Graves' disease. Proc. Natl. Acad. Sci. USA. 52:342-349.

11. Spiegelberg, H. L. 1974. Biological activities of immunoglobulins of different classes and subclasses. Adv. Immunol. 19:259-295.

12. Burton, D. R., L. Gregory, and R. Jefferis. 1986. Aspects of the molecular structure of IgG subclasses. Monogr. Allergy. 19:7-35.

13. Weetman, A. P., S. B. Cohen, D. A. Oleesky, and B. P. Morgan.
1989. Terminal complement complexes and $\mathrm{C} 1 / \mathrm{Cl}$ inhibitor complexes in autoimmune thyroid disease. Clin. Exp. Immunol. 77:25-30.

14. Morgan, B. P., R. H. Daniels, M. J. Watts, and B. D. Williams. 1988. In vivo and in vitro evidence of cell recovery from complement attack in rheumatoid synovium. Clin. Exp. Immunol. 73:467-472.

15. Weetman, A. P., C. M. Black, S. B. Cohen, R. Tomlinson, J. P. Banga, and C. B. Reimer. 1989. Affinity purification of IgG subclasses and the distribution of thyroid autoantibody activity in Hashimoto's thyroiditis. Scand. J. Immunol. 30:73-82.

16. Jefferis, R., C. B. Reimer, F. Skavaril, G. De Lange, N. R. Ling, N. R. Lowe, M. R. Walker, D. J. Phillips, C. H. Aloisio, T. W. Wells, J. P. Vaerman, C. G. Magnusson, H. Kubagawa, M. Cooper, F. Vartdal, B. Vandvik, J. J. Haaijman, O. Mäkelä, A. Sarnesto, Z. Lando, J. Gergely, E. Rajnavolgyi, G. Laszlo, J. Radl, and G. A. Molinaro. 1985. Evaluation of monoclonal antibodies having specificity for human IgG subclasses: results of an IUIS/WHO collaboration study. Immunol. Lett. 10:223-252.

17. Black, C. M., B. D. Plikaytis, T. W. Wells, R. M. Ramirez, G. M. Carlone, B. A. Chilmonczyk, and C. B. Reimer. 1988. Two site immunoenzymometric assays for serum IgG subclass infant/maternal ratios at full term. J. Immunol. Methods. 106:71-81.

18. Marshall, N. J., and P. A. Ealey. 1986. Recent developments in the in vitro bioassay of TSH and thyroid stimulating antibodies. In Immunology of Endocrine Diseases. A. M. McGregor, editor. MTP Press Ltd., Lancaster, UK. 25-49.

19. Ochi, Y., M. Yoshimura, T. Hachiya, and T. Miyazaki. 1977. Distribution of LATS activity in immunoglobulin $\mathbf{G}$ subclass. Endocrinology. 85:791-798.

20. Witte, A., B. Akyol, L. Horterer, and C. R. Pickard. 1986. Further characterisation of thyrotropin-displacing activity (TDA): evidence for restricted heterogeneity. Horm. Metab. Res. 18:858-861.

21. Bird, P., R. P. Stokes, A. G. Bird, N. R. Ling, and R. Jefferis. 1984. The separation of human serum IgG into subclass fractions by immunoaffinity chromatography and assessment of specific antibody activity. J. Immunol. Methods. 71:197-205.

22. Persson, M. A. A. 1987. Preparation of human sera containing one single IgG subclass using affinity chromatography. J. Immunol. Methods. 98:91-98.

23. Parkes, A. B., S. M. McLachlan, P. Bird, and B. Rees Smith. 1984. The distribution of microsomal and thyroglobulin antibody activity among the IgG subclasses. Clin. Exp. Immunol. 57:239-243.

24. Davies, T. F., C. M. Weber, P. Wallack, and M. Platzer. 1986. Restricted heterogeneity and $\mathrm{T}$ cell dependence of human thyroid autoantibody immunoglobulin $\mathrm{G}$ subclasses. J. Clin. Endocrinol. \& Metab. 62:945-949.

25. Weetman, A. P., and S. Cohen. 1986. The IgG subclass distribution of thyroid autoantibodies. Immunol. Lett. 13:335-341.

26. Stevens, T. F., A. Bossie, V. M. Sanders, R. Fernandez-Botram, R. L. Coffman, T. R. Mossman, and E. S. Vitetta. 1988. Regulation of antibody isotype secretion by subsets of antigen-specific helper $\mathrm{T}$ cells. Nature (Lond.). 334:255-258.

27. Lundgren, M., U. Persson, P. Larsson, C. Magnusson, C. I. E. Smith, L. Hammarstrom, and E. Severinson. 1989. Interleukin 4 induces synthesis of $\mathrm{IgE}$ and $\mathrm{IgG}_{4}$ in human B cells. Eur. J. Immunol. 19:1311-1315.

28. Weetman, A. P., A. M. McGregor, J. H. Lazarus, and R. Hall. 1982. Thyroid antibodies are produced by thyroid-derived lymphocytes. Clin. Exp. Immunol. 48:196-200.

29. McLachlan, S. M., C. A. S. Pegg, M. C. Atherton, S. L. Middleton, F. Clark, and B. Rees Smith. 1986. TSH receptor antibody synthesis by thyroid lymphocytes. Clin. Endocrinol. 24:223-230.

30. Zakarija, M., and J. M. McKenzie. 1978. Isoelectric focusing of thyroid-stimulating antibody in Graves' disease. Endocrinology. 103:1469-1475.

31. Adams, D. D., A. Knight, J. G. Knight, and P. Laing. 1987. Graves' disease: A paradigm for autoimmunity. In Thyroid Autoimmunity. A. Pinchera, S. Ingbar, J. M. McKenzie, and G. F. Fenzi, editors. Plenum Publishing Corp., New York. 1-10. 